\title{
Macroeconomic determinants of external indebtedness of Ethiopia: ARDL approach to co-integration
}

\section{SISAY DEMISSEW BEYENE ${ }^{1,2 *}$ (1) and BALÁZS KOTOSZ ${ }^{3}$}

\footnotetext{
${ }^{1}$ Faculty of Economics and Business Administration, University of Szeged, Szeged, Hungary

${ }^{2}$ College of Business and Economics, Arsi University, Asella, Ethiopia

${ }^{3}$ IÉSEG Management School, Lille, France
}

\begin{abstract}
Received: October 30, 2019 • Revised manuscript received: May 19, 2020 • Accepted: June 11, 2020
Published online: July 31, 2020

(c) 2020 The Author(s)
\end{abstract}

\begin{abstract}
Although Ethiopia is one of the Heavily Indebted Poor Countries (HIPC), there is a lack of empirical studies about the determinants of its external indebtedness. This paper aims to fill this gap by examining the macroeconomic determinants of the external indebtedness of Ethiopia between 1981 and 2016, using the two- and three-gap models as a theoretical framework and an autoregressive distributed lag bound testing approach. The result shows that in the long run, the savings-investment gap, trade deficit, fiscal deficit, and debt service have a positive and significant impact on external indebtedness. However, the growth rate of gross domestic product, trade openness, and inflation negatively and significantly affect the external indebtedness of the country. These results coincide with the predictions of the two- and three-gap models of the theoretical framework. The study argues that appropriate macroeconomic, social, and supply-side policies are essential to reducing the external indebtedness of Ethiopia.
\end{abstract}

\section{KEYWORDS}

macroeconomic determinants, external indebtedness, ARDL, Ethiopia

JEL-CODES

C32, E62

*Corresponding author. E-mail: beyene@eco.u-szeged.hu 


\section{INTRODUCTION}

External debt accumulation has been a common characteristic of developing countries at the early stage of economic development since the 1970s external debt crises (Pattillo et al. 2002). The external debt burden in most sub-Saharan African (SSA) countries became critical in the mid-1980s (Fosu 1999). Since 1980, external debt of SSA countries increased annually by 5.7\%, on the average. Such a continuous increment in external debt raised worries about the future emergence of external debt crises in sub-regions of SSA (Ampah - Kiss 2019). Hence, the issue of the determinants of external indebtedness was given significant attention after the 1970s and 1980s in developing countries in general and SSA in particular. Commonly, the causes of external debt are classified into domestic (Edo 2002; Menbere 2004; Osei 1995; Sachs 1985) and external (Cinquetti - Silva 2008; Easterly 2002; Edo 2002; Iyoha 2000; Sohn 2002) factors. According to the International Monetary Fund's (IMF 2015) classification of Heavily Indebted Poor Countries (HIPCs), Ethiopia is a severely indebted low-income country, and its external debt situation has worsened over time, making it the 10th HIPC in Africa (Africa Zeal 2017).

Excessive external debt can adversely affect investment and growth through crowding out and debt overhang effects. However, studies concerning the determinants of external debt in the case of Ethiopia are limited, even though the country is one of HIPCs. Therefore, examining the leading causes of foreign debt in the case of Ethiopia is vital to reduce its adverse impact on other macroeconomic variables and to protect the country from future unsustainable external debt and debt crisis as well. Today, due to continuous trade deficits and a narrow tax base, Ethiopia could no longer generate enough revenue to service foreign debts. That means the debt service obligation could only be met by reducing expenditures in priority areas such as education, health care systems, welfare, and social services or by additional foreign borrowing.

Ethiopia is the second most populous country in Africa and located in a strategic area in the Eastern part of Africa. Therefore, studies about Ethiopia can represent a wider region, even the HIPC or SSA countries. In the current situation of the Covid-19 induced economic crisis and the debt accumulation it is generating, other economies can draw lessons from the example of Ethiopia's quick indebtedness process. The results show the conditions under which a developing country cumulates external debt quickly, and the characteristics which make an economy vulnerable face to different domestic and external shocks. The paper also provides lessons on the limits of economic stimuli, since a part of analysed tools are widely used or in macroeconomic crisis management. Thereby, the paper provides both positive and normative responses to economic policy decision makers.

The primary objective of the study is to examine the macroeconomic determinants (savingsinvestment gap, trade deficit, budget deficit, debt service, the growth rate of advanced countries, inflation, trade openness, GDP growth rate) of external indebtedness of Ethiopia from 1981 to 2016 using the auto-regressive distributive lag (ARDL) approach by taking into account the twogap model of Chenery and Strout (1966) and Bacha's (1990) extended fiscal gap. To our knowledge, there is only a single study in the literature (Adane et al. 2018) examining the determinants of external indebtedness in the case of Ethiopia. This implies that there is a lack of empirical studies on Ethiopia, which leads to the knowledge and literature gap. In order to make concrete policy recommendations, recommendations based on a single study may not be appropriate; thus, further studies on this issue are needed. Additionally, Adane et al. (2018) did not include all the primary variables (savings-investment gap) of the two-gap model of Chenery and Strout (1966). Our study however adds the savings-investment gap and considers the three- 
gap model as a theoretical framework. Furthermore, their study used a logarithm of variables even though the variables are initially measured in rate and share of GDP, which leads to a measurement problem. Our study also incorporates more independent variables and considers both domestic and external factors in determining the external debt of Ethiopia. Also, unlike others, this study examines structural break and variance decomposition. Hence, this study can fill the knowledge and literature gaps by providing a more detailed and methodologically better founded study on Ethiopia to support appropriate policy actions.

Besides to the ARDL estimation, this study followed basic steps in econometrics such as unit root test (using both Augmented Dickey Fuller and Phillips-Perron tests), cointegration test using the Pesaran et al. (2001) bound test, structural break using the Chow test, and diagnostic tests (serial correlation, heteroskedasticity, normality, and stability tests).

The results show that the savings-investment gap, trade deficit, fiscal deficit, and debt service significantly increase the external debt of Ethiopia. However, the growth rate of gross domestic product, trade openness, and inflation negatively and significantly affect the external debt of the country. These results contribute to the literature by applying both the two- and three-gap macroeconomic models, along with the latest estimation technique and better measurement of the variables. Besides its contribution to the literature, the study provides an essential recommendation to reduce the external debt of Ethiopia, which will indirectly help to reduce the adverse effect of external debt on other macroeconomic variables.

The study is organized as follows: the next part presents the theoretical framework of the study and the empirical literature. The third section describes the methodology of the research. The fourth section presents and discusses the econometric estimation results, and the final part presents the conclusions, policy recommendations, and avenues for future research.

\section{THEORETICAL FRAMEWORK AND EMPIRICAL LITERATURE}

There are three different options - borrowing, taxation, and printing money - through which the government finances its spending and development efforts. In principle, governments borrow money to enhance the welfare of the society, to promote economic growth, and to provide public goods (Musgrave 1960). However, theories argue that if external debt grows prominent and unmanageable, it will hurt the economy.

The two-gap model pioneered by Chenery and Strout (1966) and the extension of the fiscal gap by Bacha (1990) are relevant in explaining how external debt for a country accumulates. The two-gap model models deal with the interaction between the savings and the foreign exchange constraints, while Bacha (1990) adds extended fiscal constraints. In both models, external borrowing is economically reasonable when there is a rising gap among national savings and domestic investment, foreign exchange constraint, or fiscal deficit.

The Harrod (1939) and Domar (1946) growth model is a cornerstone of the two-gap model. Using an open economy without government expenditure and GDP calculation under the expenditure approach, the model is formulated as follows:

$$
\begin{gathered}
Y=C+I+X-M \\
S-I=X-M
\end{gathered}
$$


Where $S$ is savings, $Y$ is income, $C$ is consumption, $I$ is investment, $X$ is exports, $M$ is imports, $(S-I)$ is the savings gap or internal gap, and $(X-M)$ is the trade gap (trade deficit or external gap). Since the gaps are not equal, the inflow of foreign aid or borrowing is supposed to have a dual role to resolve the difference between the savings and the trade gap (Chenery - Strout 1966). The extended three-gap model of Bacha (1990) is formulated as follows:

$$
I=\left(Y_{P}-C_{P}\right)+\left(T-G_{C}\right)+(M-X)
$$

Where $Y_{P}$ and $C_{P}$ are private income and consumption, respectively, and $T$ and $G_{C}$ are government revenues and expenditures, respectively. When government expenditure is higher than the revenues, a fiscal deficit will occur, which reduces the required investment for growth, and hence is one cause of external indebtedness. The paper uses the two-gap model (savings-investment and trade gaps) and the extended fiscal gap model developed by Bacha (1990) as its theoretical framework.

There are a number of empirical studies regarding the causes of external debt. Table 1 summarizes the existing empirical findings using different models, scopes, and results.

Table 1 divides the empirical studies into two groups: those using cross-country methods and single-country cases. The results vary depending on the methodology, the countries included, and time frame of the studies. With a few exceptions, most studies based on panel and cross-sectional data did not use the dynamic estimation techniques like panel ARDL. Similarly, only a few studies used ARDL in single-country cases (such as Abdullahi et al. 2015; Adamu - Rasiah 2016; Adane et al. 2018; and Brafu-Insaidoo et al. 2019). Table 1 also shows that among HIPCs, only Ghana, Ethiopia, and Uganda have been studied. This implies that there is a lack of country-specific empirical studies even though many countries are suffering from external debt accumulation.

\section{METHODOLOGY}

This section presents the data, sources, and data analysis. We used secondary time series data from 1981 to 2016. Data sources were the World Development Indicator (2018), the IMF (2018), and countryeconomy.com databases (2018). Table 2 summarizes the variables and their sources.

Using the two and three-gap model as a theoretical framework and using the empirical literature of the determinants of external indebtedness, we specified the following model:

$$
Y_{t}=\alpha+\beta X_{t}+\varepsilon_{t}
$$

Where $Y_{t}$ is the external debt stock to GDP ratio (ED) at period $t$.

$X_{t}$ is a vector of explanatory variables included in the model at period $t$.

$\varepsilon_{t}$ is the error terms at period $t$.

Moreover, using the theoretical and empirical findings, we identified variables of vector $X$. These capture both internal and external macroeconomic variables, which cause indebtedness directly or indirectly. These factors are the savings-investment gap (S-I), the trade deficit 
Table 1. Empirical literature

\begin{tabular}{|c|c|c|c|}
\hline Source & Model used & $\begin{array}{l}\text { Scope and } \\
\text { case studies }\end{array}$ & Results \\
\hline \multicolumn{4}{|c|}{ Groups of countries } \\
\hline \multirow{2}{*}{$\begin{array}{l}\text { Eichengreen - Portes } \\
\text { (1986) }\end{array}$} & \multirow[t]{2}{*}{ Ordinary Least Squares (OLS) } & \multirow{2}{*}{$\begin{array}{l}1930-1938 \\
20 \text { countries }\end{array}$} & +: Imports, population \\
\hline & & & -: GDP growth rate \\
\hline \multirow[t]{2}{*}{ Hajivassiliou (1987) } & \multirow[t]{2}{*}{ Random effect } & \multirow{2}{*}{\begin{tabular}{|c|}
$1970-1982$ \\
79 \\
developing \\
countries
\end{tabular}} & $\begin{array}{c}+: \text { Total debt service, import, } \\
\text { growth rate of real GNP }\end{array}$ \\
\hline & & & -: Real GNP per capita \\
\hline Menbere (2004) & Random and Fixed Effects & \begin{tabular}{|c|}
$1982-1999$ \\
60 \\
developing \\
countries
\end{tabular} & $\begin{array}{c}+ \text { : Poverty (savings gap), } \\
\text { income instability, debt service } \\
\text { payment, capital flight }\end{array}$ \\
\hline \multirow[t]{2}{*}{$\begin{array}{l}\text { Greenidge et al. } \\
\text { (2010) }\end{array}$} & \multirow[t]{2}{*}{ Dynamic OLS } & \multirow[t]{2}{*}{$\begin{array}{c}1987-2005, \\
12 \text { Caribbean } \\
\text { Community } \\
\text { countries }\end{array}$} & $\begin{array}{c}+ \text { : Difference between actual } \\
\text { and expected government } \\
\text { expenditure, depreciation of } \\
\text { currency }\end{array}$ \\
\hline & & & $\begin{array}{l}\text {-: Output gap, real effective } \\
\text { exchange rate, decline in } \\
\text { government spending. }\end{array}$ \\
\hline \multirow[t]{2}{*}{ Bittencourt (2015) } & \multirow{2}{*}{$\begin{array}{c}\text { Pooled OLS, Fixed Effects, } \\
\text { Difference GMM, System GMM }\end{array}$} & \multirow{2}{*}{\begin{tabular}{|c|}
$1970-2007$ \\
9 young \\
democracies \\
of South \\
America
\end{tabular}} & $+:$ Income inequality \\
\hline & & & $\begin{array}{c}\text {-: Economic growth, trade } \\
\text { openness, liquid liability, } \\
\text { inflation. }\end{array}$ \\
\hline Mensah et al. (2017) & Accounting and panel VAR & $\begin{array}{c}1980-2010 \\
24 \text { African } \\
\text { countries }\end{array}$ & $\begin{array}{l}+ \text { : Government investment } \\
\text { spending, consumption } \\
\text { spending, domestic } \\
\text { borrowings. - : Tax revenue, } \\
\text { inflation, output growth. }\end{array}$ \\
\hline \multirow[t]{2}{*}{ Lich - Tu (2017) } & \multirow[t]{2}{*}{ Fixed Effects } & \multirow[t]{2}{*}{$\begin{array}{l}1996-2015, \\
50 \text { countries }\end{array}$} & $\begin{array}{l}+ \text { : Debt accumulation in the } \\
\text { past, public investment, } \\
\text { exchange rate }\end{array}$ \\
\hline & & & $\begin{array}{c}-: \text { Economic growth, inflation } \\
\text { and net exports }\end{array}$ \\
\hline \multicolumn{4}{|c|}{ Single countries case studies } \\
\hline Ajayi (1991) & OLS & $\begin{array}{c}\text { 1970-1988, } \\
\text { Nigeria }\end{array}$ & $\begin{array}{l}+: \text { Deteriorating of the terms of } \\
\text { trade, the rise in foreign real }\end{array}$ \\
\hline
\end{tabular}


Table 1. Continued

\begin{tabular}{|c|c|c|c|}
\hline Source & Model used & $\begin{array}{c}\text { Scope and } \\
\text { case studies }\end{array}$ & Results \\
\hline & & & $\begin{array}{l}\text { interest rates, a fall in the } \\
\text { growth of industrial countries }\end{array}$ \\
\hline & & & $\begin{array}{c}-: \text { Improvement in the fiscal } \\
\text { positions }\end{array}$ \\
\hline Mbire - Atingi (1997) & OLS & $\begin{array}{l}\text { 1970-1995, } \\
\text { Uganda }\end{array}$ & $\begin{array}{c}+ \text { : Foreign interest rate, the real } \\
\text { effective exchange rate, } \\
\text { deterioration of the fiscal } \\
\text { position, worsening terms of } \\
\text { trade }\end{array}$ \\
\hline \multirow[t]{2}{*}{ Imimole et al. (2014) } & \multirow{2}{*}{$\begin{array}{c}\text { Error correction and the Johansen } \\
\text { cointegration test }\end{array}$} & \multirow{2}{*}{$\begin{array}{l}\text { 1986-2010, } \\
\text { Nigeria }\end{array}$} & +: Debt service, exchange rate \\
\hline & & & -: GDP growth \\
\hline \multirow[t]{2}{*}{ Abdullahi et al. (2015) } & \multirow[t]{2}{*}{ ARDL } & \multirow{2}{*}{$\begin{array}{l}\text { 1980-2013, } \\
\text { Nigeria }\end{array}$} & $+:$ National savings \\
\hline & & & $\begin{array}{c}\text {-: Exchange rate, interest rate, } \\
\text { budget deficits. }\end{array}$ \\
\hline $\begin{array}{l}\text { Adamu - Rasiah } \\
\quad(2016)\end{array}$ & ARDL & $\begin{array}{l}\text { 1970-2013, } \\
\text { Nigeria }\end{array}$ & $\begin{array}{c}+ \text { : Oil price, exchange rate, } \\
\text { debt service, gross domestic } \\
\text { saving, fiscal deficit }\end{array}$ \\
\hline \multirow[t]{2}{*}{ Adane et al. (2018) } & \multirow[t]{2}{*}{ ARDL } & \multirow[t]{2}{*}{$\begin{array}{l}\text { 1981-2016, } \\
\text { Ethiopia }\end{array}$} & $\begin{array}{c}+ \text { : Budget deficit, domestic } \\
\text { savings }\end{array}$ \\
\hline & & & $\begin{array}{c}-: \text { Inflation rate, resource } \\
\text { balance }\end{array}$ \\
\hline $\begin{array}{l}\text { Gokmenoglu - Rafik } \\
\text { (2018) }\end{array}$ & VECM and Granger causality & $\begin{array}{l}\text { 1970-2013, } \\
\text { Malaysia }\end{array}$ & $\begin{array}{c}\text { GDP, recurrent and capital } \\
\text { expenditure Granger causes } \\
\text { external debt }\end{array}$ \\
\hline \multirow[t]{2}{*}{$\begin{array}{l}\text { Brafu-Insaidoo et al. } \\
\text { (2019) }\end{array}$} & \multirow[t]{2}{*}{ ARDL } & \multirow[t]{2}{*}{$\begin{array}{c}\text { 1970-2012, } \\
\text { Ghana }\end{array}$} & $\begin{array}{l}\text { +: Reduction in regulatory } \\
\text { restrictions on external } \\
\text { borrowing, a widening of the } \\
\text { disparity between domestic and } \\
\text { international interest rates, } \\
\text { economic growth, domestic } \\
\text { financial deepening. }\end{array}$ \\
\hline & & & $\begin{array}{c}- \text { : Trade openness, } \\
\text { international debt relief. }\end{array}$ \\
\hline
\end{tabular}

Note: + and - signs imply increment and reduction of external debt stock, respectively.

Source: Authors. 
Table 2. Definitions, measurement and sources

\begin{tabular}{|l|c|c|c|}
\hline Variables & \multicolumn{1}{|c|}{ Definition } & Unit & Source \\
\hline ED & External debt as a percentage of GDP & Percentage & WDI database \\
\hline S-I & $\begin{array}{r}\text { The savings-investment gap as a percentage } \\
\text { of GP }\end{array}$ & Percentage & IMF database \\
\hline TRDEF & Trade deficit as a percentage of GDP & Percentage & WDI database \\
\hline BDDEF & Budget deficit as a percentage of GDP & Percentage & countryeconomy.com database \\
\hline DSR & $\begin{array}{c}\text { Debt service as a percentage of exports of } \\
\text { goods, services and primary income. }\end{array}$ & Percentage & WDI database \\
\hline OPPN & Trade openness as a percentage of GDP & Percentage & WDI database \\
\hline GRMAC & The growth rate of major advanced countries & Percentage & WDI database \\
\hline INF & Inflation rate & Percentage & WDI database \\
\hline GDPGR & Real GDP growth rate & Percentage & IMF database \\
\hline
\end{tabular}

Source: Authors.

(TRDEF), the budget deficit (BDDEF), debt service (DSR), the growth rate of major advanced countries (GRMAC), inflation (INF), trade openness (OPPN), and GDP growth rate (GDPGR). Therefore, $X^{1}$ can be written as:

$$
X_{t}=f(S-I, \text { TRDEF, BDDEF, DSR, GRMAC, INF, OPPN, GDPGR })
$$

More specifically, the model we used is:

$$
\begin{aligned}
E D_{t}= & \beta_{0}+\beta_{1}(S-I)_{t}+\beta_{2} T_{R D E F_{t}}+\beta_{3} \mathrm{BDDEF}_{t}+\beta_{4} D S R_{t}+\beta_{5} \mathrm{GRMAC}_{t}+\beta_{6} I N F_{t}+\beta_{7} \mathrm{OPPN}_{t}+\beta_{8} \mathrm{GDPGR}_{t} \\
& +\varepsilon_{t}
\end{aligned}
$$

where, $\beta_{0}$ is an intercept term, and $(+) \beta_{1},(+) \beta_{2},(+) \beta_{3},(+) \beta_{4},(-) \beta_{5},( \pm) \beta_{6},( \pm) \beta_{7}$, and (-) $\beta_{8}$ are the long-run coefficients that are estimated using ARDL. The signs in the parentheses are the expected hypothesized signs of the variables.

The methodology we have used in this study is the ARDL bound testing approach. We adopted this approach due to its several advantages over the conventional type of cointegration techniques (Bakry - Almohamad, 2018; Fosu - Magnus 2006). For example, the Johansen cointegration approach has a nature of complexity, needs all variables to be the same order of integrations (I(1)), is less efficient in small numbers of observation, inefficient and leads to contrary results when there are more than two I(1) variables. Furthermore, the Johansen cointegration approach does not

\footnotetext{
${ }^{1}$ Here, we selected basic macroeconomic variables as determinants of external debt. For example, the real exchange rate plays a significant role in influencing foreign debt. A growth spike, a rise in inflation, and a boom in trade could all lead to a persistent real exchange rate appreciation, which in turn reduces external debt as a percentage of GDP. However, due to the ADF test result of I(2), we did not include it in the model.
} 
Table 3. Unit root test

\begin{tabular}{|l|l|r|r|r|r|}
\hline \multirow{2}{*}{ Variables } & \multicolumn{2}{|r|}{$\begin{array}{r}\text { ADF test statistics (with trend } \\
\text { and intercept) }\end{array}$} & $\begin{array}{r}\text { P-P test statistics (with trend } \\
\text { and intercept) }\end{array}$ & \multirow{2}{*}{ Order of integration } \\
\cline { 2 - 5 } & Level & First diff & Level & First diff & I(1) \\
\hline ED & -2.46 & $-4.94 * * *$ & -2.45 & $-4.96^{* * *}$ & $\mathrm{I}(1)$ \\
\hline S-I & -0.48 & $-10.22^{* * *}$ & $-4.33^{* * *}$ & $-11.33^{* * *}$ & $\mathrm{I}(1)$ \\
\hline TRDEF & -3.07 & $-8.33^{* * *}$ & -3.09 & $-8.59 * * *$ & $\mathrm{I}(1)$ \\
\hline BDDEF & $-4.11^{* *}$ & $-6.70^{* * *}$ & $-4.12^{* *}$ & $-10.52^{* * *}$ & $\mathrm{I}(1)$ \\
\hline DSR & -2.70 & $-4.53^{* * *}$ & -2.63 & $-7.16^{* * *}$ & $\mathrm{I}(0)$ \\
\hline GRMAC & $-4.57^{* * *}$ & $-6.32^{* * *}$ & $-4.56^{* * *}$ & $-17.20^{* * *}$ & $\mathrm{I}(0)$ \\
\hline INF & $-4.94^{* * *}$ & $-8.24 * * *$ & $-4.94 * * *$ & $-12.51^{* * *}$ & $\mathrm{I}(1)$ \\
\hline OPPN & -1.08 & $-5.65^{* * *}$ & $-1.11^{* * *}$ & $-5.65^{* * *}$ & $\mathrm{I}(1)$ \\
\hline GDPGR & $-4.2 * *$ & $-8.96^{* * *}$ & $-5.94^{* * *}$ & $-19.41^{* * *}$ & \\
\hline
\end{tabular}

Notes: $* * *$ Significant at the $1 \%$ level; ${ }^{* *}$ Significant at the $5 \%$ level; ${ }^{*}$ Significant at the $10 \%$ level. All the values in the table are $t$-statistics.

Source: Authors, based on WDI, IMF, and countryeconomy.com databases, using Eviews 9.

include information on the structural break in time series data and suffers from low predicting power, and is very sensitive to the lag length selected for the Vector Error Correction Model (VECM) (Brook 2008). Further, it provides biased estimates of the long-run model when some of the regressors are endogenous, being very sensitive to the assumption that errors are independent and normally distributed (Maddala - Kim 1998). However, ARDL solves the above shortcomings in time-series studies. Hence, to analyse the long-run relationships and dynamic interactions among the variables of interest, the model is estimated by using the bounds testing approach, initially introduced by Shin and Pesaran (1999) and further extended by Pesaran and colleagues (2001). The ARDL model used in this study is presented in Eq. (7).

$$
\begin{aligned}
& \Delta E D_{t}=\alpha_{0}+\sum_{i=1}^{p} \beta \Delta E D_{t-i}+\sum_{i=0}^{q} \delta \Delta(S-I)_{t-i}+\sum_{i=0}^{r} \gamma \Delta \operatorname{TRDEF}_{t-i}+\sum_{i=0}^{s} \mu \Delta B D D E F_{t-i} \\
& +\sum_{i=0}^{t} \rho \Delta D S R_{t-i}+\sum_{i=0}^{u} \varphi \Delta \operatorname{GRMAC}_{t-i}+\sum_{i=0}^{v} \omega \Delta I N F_{t-i} \\
& +\sum_{i=0}^{w} \sigma \Delta O P P N_{t-i}+\sum_{i=0}^{x} \tau \Delta \operatorname{GDPGR}_{t-i}+b_{0} E D_{t-1}+b_{1}(S-I)_{t-1} \\
& +b_{2} \text { TRDEF }_{t-1}+b_{3} \text { BDDEF }_{t-1}+b_{4} D S R_{t-1}+b_{5} \text { GRMAC }_{t-1} \\
& +b_{6} I N F_{t-1}+b_{7} \text { OPPN }_{t-1}+b_{8} \text { GRMAC }_{t-1}+v_{t}
\end{aligned}
$$

Where, $b_{1}, b_{2}, b_{3}, b_{4}, b_{5}, b_{6}, b_{7}$, and $b_{8}$ are long-run multipliers, $\alpha_{0}$ is a drift (constant term), and the coefficients of lagged values of differences of the variables show the short-run dynamic structure. Furthermore, $\Delta$ is the first difference operator, and $p$ is the maximum lag length. 
Table 4. Cointegration test

\begin{tabular}{|c|c|c|c|c|c|}
\hline \multirow{2}{*}{$\begin{array}{l}\text { Test statistics } \\
\text { F- statistics }\end{array}$} & \multirow{2}{*}{$\begin{array}{c}\text { Value } \\
4.40\end{array}$} & \multirow{2}{*}{$\frac{\text { No. of independent variables }}{8}$} & \multirow[t]{2}{*}{ Significance level } & \multicolumn{2}{|c|}{$\begin{array}{r}\text { Bound critical } \\
\text { values } \\
\text { (unrestricted } \\
\text { intercept and no } \\
\text { trend) }\end{array}$} \\
\hline & & & & $\mathrm{I}(0)$ & $\mathrm{I}(1)$ \\
\hline & & & $10 \%$ & 1.95 & 3.06 \\
\hline & & & $5 \%$ & 2.22 & 3.39 \\
\hline & & & $2.5 \%$ & 2.48 & 3.70 \\
\hline & & & $1 \%$ & 2.79 & 4.10 \\
\hline
\end{tabular}

Notes: Pesaran et al. (2001) bound critical values.

Source: Authors, based on WDI, IMF, and countryeconomy.com databases, using Eviews 9.

The primary step in the ARDL approach is testing for the stationarity status of all variables to determine their order of integration. To avoid spurious results, it is necessary to confirm that none of the variables is integrated of order two or beyond (Fosu - Magnus 2006). The second step is the selection of the maximum lag length using different information criteria before we estimate the model. However, Narayan (2005) and Shin and Pesaran (1999) suggested choosing two as the maximum order of lags if the observations are annual. Once the maximum lag length is determined, the third step is an estimation of the general Eq. (7) and then testing the existence of a long-run relationship among the variables by conducting an F-test for the joint significance of the coefficients of the lagged levels of the variables. The fourth step is an estimation of the long-run and short-run relationships simultaneously. Once cointegration is established, the VECM long-run model is specified (see Eq. (8)):

$$
\begin{aligned}
E D_{t}= & \beta_{0}+\sum_{i=1}^{p} \beta E D_{t-i}+\sum_{i=0}^{q} \beta_{1}(S-I)_{t-i}+\sum_{i=0}^{r} \beta_{2} \operatorname{TRDEF}_{t-i}+\sum_{i=0}^{s} \beta_{3} \text { BDDEF }_{t-i} \\
& +\sum_{\substack{i=0 \\
\text { ind }}}^{t} \beta_{4} D S R_{t-i}+\sum_{i=0}^{u} \beta_{5} \text { GRMAC }_{t-i}+\sum_{i=0}^{v} \beta_{6} I N F_{t-i}+\sum_{i=0}^{w} \beta_{7} \text { OPPN }_{t-i} \\
& +\sum_{i=0}^{x} \beta_{8} \text { GDPGR }_{t-i}+\varepsilon_{t}
\end{aligned}
$$

This involves selecting the orders of the ARDL $(p, q, r, s, t, u, v, w, x)$ for the model using Akaike information criterion (AIC) Schwarz-Bayesian information criteria (SBC). The ARDL specification of the short-run dynamics is derived by constructing an error correction model (ECM) in the following form (see Eq. (9)): 
Table 5. Estimated Long Run Coefficients of the Indebtedness Model ARDL $(1,0,1,1,2,0,0,2,1)$ selected based on Akaike info criterion (AIC). The dependent variable is ED

\begin{tabular}{|l|c|c|}
\hline Variables & Coefficients & T-statistics [Prob] \\
\hline S-I & 2.95 & $2.83[0.011]^{* *}$ \\
\hline TRDEF & 3.22 & $1.77[0.0944]^{*}$ \\
\hline BDDEF & 7.56 & $2.77[0.0131]^{* *}$ \\
\hline DSR & 1.12 & $2.19[0.0424]^{* *}$ \\
\hline GRMAC & -0.08 & $-0.08[0.9329]$ \\
\hline INF & -0.81 & $-2.33[0.0322]^{* *}$ \\
\hline OPPN & -2.79 & $-2.78[0.0128]^{* *}$ \\
\hline GDPGR & -3.64 & $-2.39[0.0282]^{* *}$ \\
\hline Constant & 161.80 & $5.41[0.0000]^{* * *}$ \\
\hline R-squared & 0.980720 & \\
\hline F-statistic & 54.04644 & \\
\hline Prob (F-stat) & 0.000000 & \\
\hline D-W stat & 1.778406 & \\
\hline
\end{tabular}

Notes: *** Significant at the $1 \%$ level; ** Significant at the $5 \%$ level; * Significant at the $10 \%$ level.

Source: Authors, based on WDI, IMF, and countryeconomy.com databases, using Eviews 9.

$$
\begin{aligned}
\Delta E D_{t}= & \theta_{0}+\sum_{i=1}^{p} \theta \Delta E D_{t-i}+\sum_{i=0}^{q} \theta_{1} \Delta(S-I)_{t-i}+\sum_{i=0}^{r} \theta_{2} \Delta \operatorname{TRDEF}_{t-i}+\sum_{i=0}^{s} \theta_{3} \Delta \mathrm{BDDEF}_{t-i} \\
& +\sum_{\substack{i=0 \\
\text { t }}}^{t} \theta_{4} \Delta D S R_{t-i}+\sum_{i=0}^{u} \theta_{5} \Delta \mathrm{GRMAC}_{t-i}+\sum_{i=0}^{v} \theta_{6} \Delta I N F_{t-i}+\sum_{i=0}^{w} \theta_{7} \Delta \mathrm{OPPN}_{t-i} \\
& +\sum_{i=0}^{x} \theta_{8} \Delta \mathrm{GDPGR}_{t-i}+\lambda \mathrm{ecm}_{t-1}+\varepsilon_{t}
\end{aligned}
$$

where all coefficients of the short-run equation are coefficients relating to the short-run dynamics of the model convergence to equilibrium, $\lambda$ is the speed of adjustment parameter, and $e c m_{t-1}$ is the one period lagged error correction term. Finally, it is necessary to run diagnostic tests, such as serial correlation using the Breusch-Godfrey serial correlation Lagrange multiplier (LM) test, heteroskedasticity test using the Breusch-Pagan-Godfrey test, normality test using the Jarque-Bera test, and stability tests using Cumulative sum (CUSUM) and CUSUM of squares.

\section{RESULTS AND DISCUSSION}

The econometric results and their interpretations along with the empirical support of the study are presented in this section. More specifically, the unit root test using Augmented Dickey-Fuller 
Table 6. Estimated short-run coefficients of the indebtedness model ARDL $(1,0,1,1,2,0,0,2,1)$ selected based on Akaike info criterion (AIC). The dependent variable is $D(E D)$

\begin{tabular}{|l|c|c|}
\hline Variables & Coefficients & T-statistics [Prob] \\
\hline D(S_I) & 1.215 & $2.745[0.0138]^{* *}$ \\
\hline D(TRDEF) & 0.129 & $0.250[0.8053]$ \\
\hline D(BDDEF) & 2.324 & $2.699[0.0152]^{* *}$ \\
\hline D(DSR) & 0.051 & $0.238[0.8147]$ \\
\hline D(DSR(-1)) & -0.521 & $-2.554[0.0205]^{* *}$ \\
\hline D(GRMAC) & -0.085 & $-0.085[0.9328]$ \\
\hline D(INF) & -0.336 & $-2.327[0.0326]^{* *}$ \\
\hline D(OPPN) & -0.540 & $-1.205[0.2444]$ \\
\hline D(GDPGR) & -1.087 & $-3.378[0.0036]^{* * *}$ \\
\hline D(GDPGR(-1)) & 0.696 & $-5.786[0.0000]^{* * *}$ \\
\hline ECM(-1) & -0.411 & $-5.786[0.0000]^{* * *}$ \\
\hline
\end{tabular}

Notes: *** Significant at the $1 \%$ level; ** Significant at the $5 \%$ level; * Significant at the $10 \%$ level.

Source: Authors, based on WDI, IMF, and countryeconomy.com databases, using Eviews 9.

and Phillips-Perron, cointegration test, long-run and short-run dynamics, and diagnostic tests (normality, heteroscedasticity, autocorrelation, and stability) of the model are presented.

\subsection{Unit root, structural break, and cointegration tests}

Before checking the presence of the long-run relationship (cointegration) between the variables, we checked the order of integration of each variable in the model by using the Augmented Dickey-Fuller (ADF) and Phillips-Perron (P-P) tests. The result shows that GRMAC and INF are $\mathrm{I}(0)$, the other variables are $\mathrm{I}(1)$. There is no variable which has $\mathrm{I}(2)$, and therefore, ARDL could proceed (see Table 3 ). The cointegration test result implies that the null hypothesis of no cointegration is rejected at the $1 \%$ level (see Table 4). The calculated F statistics are shown in Table 3. The critical values are reported together in the same table, which is based on Pesaran et al. (2001). ${ }^{2}$ The calculated F-statistic of the model is 4.4, which is higher than the upper bound critical values at the $1 \%$ critical level of significance. This implies that the null hypothesis of no cointegration is rejected at the $1 \%$ level. As a result, in the model, there is a cointegration relationship among the variables.

Furthermore, to prevent our model from significant forecasting errors and unreliability, we tested the structural break using the Chow test. Initially, we identified the sharp change year

\footnotetext{
${ }^{2}$ There are two types of bound test critical value tables: the Pesaran et al. (2001) and Narayan (2004) tables of critical values. We chose the former because Narayan (2005) does not have values if there are more independent variables than seven.
} 
(1992) by plotting the graph for the dependent variable. Having this, we estimated the model and conducted the Chow breakpoint test. The result confirmed that the null hypothesis of no breakpoint is accepted (see Appendix 1).

\subsection{The long-run estimation results}

In the model, the explanatory variables together explain over $98 \%$ of the systematic variation in external debt during the period being studied. The F-value of 54.04 is highly significant, passing the significance test at the $1 \%$ level. The Durbin-Watson result (1.77) shows the absence of serial correlation of the residuals in the system. The long-run equilibrium coefficients and their asymptotic standard error, $t$-values, and $P$-values are presented in Table 5.

All independent variables except the growth rate of advanced countries are significant variables, which appear to affect the external indebtedness of Ethiopia. The savings-investment gap, trade deficit, fiscal deficit, and debt services positively and significantly affect the external indebtedness of Ethiopia independently. The rise in the savings-investment gap, trade deficit, fiscal deficit, and debt services by one percentage point results in increases in the external debt of Ethiopia by $2.95,3.22,7.56$, and 1.12 percentage points, respectively. The reason behind this is that the savings-investment gap, trade deficit and fiscal deficit leads all lead to a resource gap. As a result, the country is forced to borrow from foreign entities to fill this gap. The coefficient of the trade deficit shows that Ethiopia's external debt is not sustainable in terms of willingness and ability to pay, because from the estimated coefficient the country's trade balance (deficit), which is one source of servicing debt, causes external debt accumulation. Additionally, the debt service payment incites further demand for external borrowing, leading to a spiral of indebtedness. This result is also consistent with the work of Menbere (2004) for the savings-investment gap variable; Mbire and Atingi (1997) for the trade deficit variable; for budget deficit variable (Adamu - Rasiah 2016; Adane et al. 2018; Ajayi 1991; Mbire - Atingi 1997); for debt service variable (Hajivassiliou 1987; Imimole et al. 2014; Menbere 2004). However, the methodology they used has some limitations relative to our methodology. For example, Ajayi (1991), and Mbire and Atingi (1997) used conventional OLS, and their studies are also somewhat outdated, as they focused on the 1980s and 1990s debt crises. Further, Imimole et al. (2014) used the error correction and the Johansen cointegration test in their analysis. Hence, our study tried to take into account the methodological and time gap. Furthermore, the above studies did not use the three-gap model to inform the choice of regressors (savings-investment, budget deficit, and trade deficit). In addition, different from others, this study added inflation as an independent variable, and our result supports the hypothesised positive sign derived from the theoretical framework.

Inflation, GDP growth, and trade openness negatively and significantly affect the external indebtedness of the country. The rise in inflation by one percentage point results in decreasing external debt by 0.81 percentage points. The reason could be inflation reduced investment, thus allowing the reduction of the savings-investment gap. Furthermore, this result coincides with the work of Bittencourt (2015), Lich and Tu (2017), and Adane et al. (2018). However, more than $50 \%$ of the variables in our study are different from those of Bittencourt (2015). For example, he did not consider any variables from the three-gap model even though they are the primary sources of indebtedness. Similarly, Adane et al. (2018) did not fully take into account the threegap models' variables. Unlike Bittencourt (2015) and Lich and Tu (2017), this study focuses only on one country case (Ethiopia). 
Furthermore, a one percentage point rise in the GDP growth rate reduces the external debt by 3.64 percentage points. This is because when the economy grows, the resource gap can be reduced, thus reducing external indebtedness. This result is similar to a number of works in the literature (Bittencourt 2015; Eichengreen - Portes 1986; Greenidge et al. 2010; Hajivassiliou 1987; Imimole et al. 2014; Lich - Tu 2017; Menbere 2004).

Some contributions in the literature argue that the financial and economic crisis changed the world economy, and that developing countries in particular have been affected by the crisis, although the impact was somewhat delayed. The crisis was transmitted primarily by trade and financial flows, forcing millions back into poverty. Attainment of the Millennium Development Goals was seriously jeopardised in many countries. Many developing countries did not have the resources to stimulate their economies. Hence, the time frame of our study (1981-2016) captured the 1980s and 1990s global debt crisis, the financial and economic crisis of 2008, and the dawn of the African and SSA economic boom since 2000.

The increase in the trade openness of the country by one percentage point reduces the external debt by 2.79 percentage points. This is because trade openness allocates resources both domestically and on an international level. Thus, it reduces the resource gaps by increasing GDP, increases foreign exchange through exports, and subsequently increases the debt service capacity of the country. All of these factors minimize a country's external debt. This result is also consistent with the findings of Bittencourt (2015).

Relative to other variables, the budget deficit has the most significant influence in increasing the external debt accumulation of Ethiopia. Increasing GDP growth has a significant influence in reducing external debt. However, the contribution of the growth rate of major advanced countries in reducing debt accumulation is limited.

\subsection{The short-run estimation results}

The short-run result or the ECM is presented in Table 6. In the short run, external indebtedness is positively and significantly affected by the level difference of the savings-investment gap and budget deficit. In the short run, the rise in the level difference of the savings-investment gap and budget deficits by one percentage point results in increases in the external debt of Ethiopia by 1.21 and 2.32 percentage points, respectively. This result, as well as the reasoning behind it, is consistent with the long-run equilibrium result that we have discussed above.

However, in the short run, external indebtedness is negatively and significantly affected by the difference in inflation and GDP growth rate. The rise in the level difference of inflation and GDP growth by one percentage point results in a decrease in the external debt of Ethiopia by 0.33 and 1.08 percentage point respectively. Current debt service insignificantly increases external debt because if debt repayment is compulsory, the country needs to borrow from somewhere and these lead to increasing the borrowing interest rate, hence reducing the demand for borrowing. The increase of the lagged debt service variable significantly decreases current debt. Furthermore, the external debt accumulation of Ethiopia is positively and significantly affected by the lag difference in GDP growth.

The error correction term indicates the speed of adjustment to restore equilibrium in the dynamic model. The ECM coefficient shows how quickly variables converge to equilibrium, and theoretically, it should have a statistically significant coefficient with a negative sign. This condition occurs in our model. Furthermore, the highly significant error correction term 
confirms the existence of a stable long-run relationship between variables. The coefficient of ECM $(-1)$ is -0.411 , implying that about $41 \%$ of the deviation of the actual external debt from its equilibrium value is eliminated every year; hence, in this study, full adjustment to reach equilibrium would require almost two and a half years (see Table 6). Furthermore, compared with other variables in the model, the coefficient of ECM supports the argument that the external debt of Ethiopia is sustainable.

In addition to the short-run estimation result, this study used variance decomposition analysis to forecast as well as measure the influence of the independent variable on the dependent variable (see Appendix 2). The Appendix shows that the forecast error variance for a particular period is $100 \%$. In the short run, a $100 \%$ forecast error variance in external debt is explained by itself. However, from the second period onwards, debt service, budget deficit, the growth rate of major advanced countries, inflation, and openness have a strong influence in the short run as well as in the long run. However, the savings-investment gap and trade deficit have a strong influence only in the long run. For example, in period 10, the variance contribution of external debt itself is 11.776 , while the variance contribution of debt service and the growth rate of major advanced countries to external debt is 26.36 and 14.67 , respectively.

Finally, the diagnostic tests of the model, such as the normality test of Jarque-Bera, the serialcorrelation test of Breusch-Godfrey LM, the heteroskedasticity test of Breusch-Pagan-Godfrey, the stability test of recursive residuals (CUSUM), and the CUSUM of square (CUSUMSQ) tests have been conducted. The estimated residuals did not provide any significant evidence of non-normality, serial-correlation, non-stability, or heteroskedasticity in the error term (see Appendix 3).

\section{CONCLUSIONS}

At the early stage of economic growth, due to the existence of resource gaps, borrowing from abroad is a common characteristic of the developing countries, including Ethiopia. However, unmanageable, and unsustainable external debt accumulation can adversely affect the macroeconomic variables and can be a bottleneck for the economy. Therefore, the main objective of this study was to examine the determinants of external indebtedness of Ethiopia for the period between 1981 and 2016, employing the ARDL cointegration approach. The study included both internal and external macroeconomic variables in the model. Furthermore, it used all the basic tests including the stationary test, structural break test, cointegration test, both long run and short run estimations, and the diagnostic tests. The results showed that the savings-investment gap, trade deficit, fiscal deficit, and debt service have a positive and significant impact on determining the external debt of Ethiopia. All these variables lead to resource gaps as a result, forcing the country to borrow from foreign entities. Furthermore, inflation, trade openness, and GDP growth have a negative and significant impact on the external debt of Ethiopia.

Based on our findings and intuitive knowledge, we can recommend that increasing domestic savings via promoting domestic savings habits; following appropriate macroeconomic policies (on consumption, income, and interest rates); and maintaining political stability are essential. Furthermore, even though spending for developmental purposes is vital, the need for budgetary reform is evident. Hence, to reduce fiscal deficits, steps must be taken either to raise the efficiency of tax collection or to cut unnecessary spending. There should also be significant efforts to improve the performance of the productive sectors to increase GDP. Additionally, increasing 
exports and reducing imports via the exchange rate policies of devaluation and supply-side policies by improving the productivity and competitiveness of the economy are essential.

Finally, even though this study tried to resolve the existing methodological issues in the literature, it still has limitations. This study was restricted to macroeconomic variables, and therefore, other non-macroeconomic variables - such as natural disasters, institutional factors, and the political environment - were omitted. Furthermore, it did not investigate causation, only relationships. Hence, future researchers can extend the investigation by taking these factors into account.

\section{ACKNOWLEDGEMENT}

This research was supported by the project EFOP-3.6.2-16-2017-00007, titled 'Aspects on the development of intelligent, sustainable and inclusive society: social, technological, innovation networks in employment and digital economy.' The project has been supported by the European Union, co-financed by the European Social Fund and the budget of Hungary. The contents of the paper are the sole responsibility of the authors and can under no circumstances be regarded as reflecting the position of the European Union.

\section{REFERENCES}

Abdullahi, M. M. - Bakar, N. - Hassan, S. B. (2015): Determining the Macroeconomic Factors of External Debt Accumulation in Nigeria: An ARDL Bound Test Approach. Procedia-Social and Behavioral Sciences 211: 745-752.

Adamu, I. - Rasiah, R. (2016): On the Determinants of External Debt in Nigeria. African Development Review 28(3): 291-303.

Adane, O. - Mulugeta, W. - Melaku, T. (2018): Determinants of External Debt in Ethiopia. Journal of Business and Economics 2(1): 128-131.

Africa Zeal (2017): Most Indebted African Countries. http://www.africanzeal.com/african-indebtedcountries/, accessed 11/04/2017.

Ajayi, S. I. (1991): Macroeconomic Approach to External Debt: A Case of Nigeria. African Economic Research Consortium Research Paper No. 8.

Ampah, I. K. - Kiss, G. D. (2019): Economic Policy Implications of External Debt and Capital Flight in Sub-Saharan Africa's Heavily Indebted Poor Countries. Society and Economy 41(4): 523-542.

Bacha, E. L. (1990): A Three-gap Model of Foreign Transfers and the GDP Growth Rate in Developing Countries. Journal of Development Economics 32(2): 279-296.

Bakry, W. - Almohamad, S. (2018): Further Evidence on Middle East and North Africa Financial Markets Integration: International Journal of Economics and Business Research 15(1): 1-22.

Bittencourt, M. (2015): Determinants of Government and External Debt. Evidence from the Young Democracies of South America. Emerging Markets Finance and Trade 51(3): 463-472.

Brafu-Insaidoo, W. G. - Ahiakpor, F. - Vera Ogeh, F. - William, G. C. (2019): Macro-Determinants of Short-term Foreign Debt in Ghana. Cogent Economics \& Finance 7(1): 1-17.

Brooks, C. (2008): Introductory Econometrics for Finance (2nd ed.). New York: Cambridge University Press. 
Chenery, H. B. - Strout, A. M. (1966): Foreign Assistance and Economic Development. American Economic Review 56(4): 679-733.

Cinquetti, C. A. - Silva, R. G. (2008): Delays in Stabilization or in Reforms? The Debt Crisis. The Developing Economies 46(3): 290-314.

Domar, E. D. (1946): Capital Expansion, Rate of Growth, and Employment. Econometrica 14(2): 137-147.

Easterly, W. (2002): How Did Heavily Indebted Poor Countries Become Heavily Indebted? Reviewing Two Decades of Debt Relief. World Development 30(10): 1677-1696.

Edo, S. (2002): The External Debt Problem in Africa: A Comparative study of Nigeria and Morocco. African Development Review 14(2): 221-236.

Eichengreen, B. - Portes, R. (1986): Debt and Default in the 1930s: Causes and Consequences. European Economic Review 30(3): 599-640.

Fosu, A. K. (1999): The External Debt Burden and Economic Growth in the 1980s: Evidence from SubSaharan Africa. Canadian Journal of Development Studies 20(2): 307-318.

Fosu, O. - Magnus, F. (2006): An Examination of Foreign Direct Investment, Trade and Growth Relationships: A Case of Ghana. American Journal of Applied Science 3(11): 2079-2085.

Gokmenoglu, K. - Rafik, R. A. M. (2018): Determinants of External Debt: The Case of Malaysia. In: Ozatac, N. - Gokmenoglu, K. (eds.) Emerging Trends in Banking and Finance. Cham: Springer, Ch. 2.

Greenidge, K. - Drakes, L. - Craigwell, R. (2010): The External Public Debt. A case of the Caribbean Community. Journal of Policy Modeling 32(3): 418-431.

Hajivassiliou, V. A. (1987): The External Debt Repayments Problems of LDC's: An Econometric Model. Journal of Econometrics 36(1-2): 205-230.

Harrod, R. F (1939): An Essay in Dynamic Theory. The Economic Journal 49(193): 14-33.

IMF (2018): Knoema Database. https://knoema.com/atlas/sources/IMF, accessed 18/06/2020.

IMF (Various years): International Financial Statistics Yearbook. Washington, DC: IMF.

Imimole, B. - Imoughele, L. E. - Okhuese, M. A. (2014): Determinants and Sustainability of External Debt in a Deregulated Economy: A Co-integration an-alysis from Nigeria (1986-2010). American International Journal of Contemporary Research 4(6): 201-214.

Iyoha, M. A. (2000): External Debt and Capital Flights in Sub-Saharan Africa. In Khan, M. S. - Ajayi, S. I. (eds.) An Econometric Analysis of External Debt and Economic Growth in Sub-Saharan African Countries. Washington, DC: IMF.

Lich, H. K. - Tu, D. C. (2017): Determinants of External Debt in Developing Countries. VNU Journal of Science: Economics and Business 33(4): 103-110.

Maddala, G. S. - Kim, I.-M. (1998): Unit Roots, Cointegration and Structural Change. Cambridge: Cambridge University Press.

Mbire, B. - Atingi, M. (1997): Growth and Foreign Debt: The Ugandan Experience. African Economic Research Consortium Research Paper 66.

Menbere, W. T. (2004): An Empirical Investigation into the Determinants of External Indebtedness: A Case Study of 60 Developing Countries. Prague Economic Papers 3: 261-277.

Mensah, D. - Aboagye, A. Q. Q. - Abor, J. Y. - Kyereboah-Coleman, A. (2017): External Debt Among HIPCs in Africa: Accounting and Panel VAR Analysis of Some Determinant. Journal of Economic Studies 44(3): $431-$ 455.

Musgrave, R. A. (1960): The Theory of Public Finance. Southern Economic Journal 26(3): 234-238.

Narayan, P. K. (2004): Fiji's Tourism Demand: The ARDL Approach to Cointegration. Tourism Economics 10(2): 193-206. 
Narayan, P. K. (2005): The Saving and Investment Nexus for China: Evidence from Co-integration Tests. Applied Economics 37(17): 1979-1990.

Osei, B. (1995): Ghana: The Burden of Debt Service Payment under Structural Adjustment. African Economic Research Consortium Research Paper 33.

Pattillo, C. A. - Poirson, H. - Ricci, L. A. (2002): External Debt and Growth. IMF Working Paper 02/69.

Pesaran, M. H. - Shin, Y. - Smith, R. J. (2001): Bound Testing Approaches to the Analysis of Level Relationships. Journal of Applied Econometrics 16(3): 289-326.

Sachs, J. (1985): Theoretical Issues in International Borrowing. Princeton Studies in International Finance 54.

Shin, Y. - Pesaran, M. H. (1999): An Autoregressive Distributed Lag Modelling Approach to Cointegration Analysis. In S. Strom (ed.) Econometrics and Economic Theory in the 20th Century: The Ragnar Frish Centennial Symposium. Cambridge: Cambridge University Press, pp. 371-413.

Sohn, C.-H. (2002): Corporate Debt Resolution and the Role of Foreign Capital in the Post-Crisis Restructuring of the Republic of Korea. The Developing Economies 40(4): 564-586. 


\section{APPENDIX 1. CHOW BREAKPOINT TEST: 1992}

Null Hypothesis: No breaks at specified breakpoints.

\begin{tabular}{|l|c|c|c|}
\hline F-statistic & 0.996119 & Prob. F(8,20) & 0.4685 \\
\hline Log likelihood ratio & 12.07306 & Prob. Chi-Square(8) & 0.1480 \\
\hline Wald Statistic & 7.968953 & Prob. Chi-Square(8) & 0.4365 \\
\hline
\end{tabular}

Source: Authors, based on WDI, IMF, and countryeconomy.com database, using Eviews 9.

\section{APPENDIX 2. VARIANCE DECOMPOSITION OF ED}

\begin{tabular}{|l|r|r|r|r|r|r|r|r|r|l|}
\hline Period & S.E. & ED & S-I & TRDEF & BDDEF & DSR & GRMAC & INF & OPPN & GDPGR \\
\hline 1 & 7.400 & 100.000 & 0.000 & 0.000 & 0.000 & 0.000 & 0.000 & 0.000 & 0.000 & 0.000 \\
\hline 2 & 9.789 & 82.339 & 0.0001 & 0.595 & 0.019 & 1.5187 & 1.103 & 3.573 & 10.721 & 0.127 \\
\hline 3 & 12.516 & 56.605 & 0.059 & 0.610 & 5.168 & 20.609 & 2.657 & 4.544 & 9.601 & 0.143 \\
\hline 4 & 13.51 & 50.328 & 0.375 & 0.938 & 7.203 & 22.898 & 2.451 & 6.927 & 8.465 & 0.411 \\
\hline 5 & 15.604 & 37.920 & 4.570 & 1.850 & 6.651 & 24.070 & 4.723 & 6.651 & 9.405 & 4.156 \\
\hline 6 & 18.347 & 27.801 & 8.566 & 2.479 & 5.228 & 26.459 & 7.188 & 8.522 & 9.199 & 4.555 \\
\hline 7 & 21.878 & 20.88 & 9.857 & 2.156 & 5.319 & 25.896 & 10.579 & 9.409 & 10.138 & 5.761 \\
\hline 8 & 25.244 & 16.017 & 10.302 & 1.736 & 5.271 & 25.980 & 12.950 & 9.084 & 10.747 & 7.908 \\
\hline 9 & 27.682 & 13.332 & 10.589 & 1.736 & 4.986 & 26.573 & 13.926 & 9.553 & 10.869 & 8.433 \\
\hline 10 & 29.462 & 11.776 & 10.910 & 1.681 & 5.237 & 26.367 & 14.672 & 9.825 & 10.959 & 8.569 \\
\hline
\end{tabular}

Source: Authors, based on WDI, IMF, and countryeconomy.com database, using Eviews 9. 


\section{APPENDIX 3. DIAGNOSTIC TESTS}

A, Normality Test

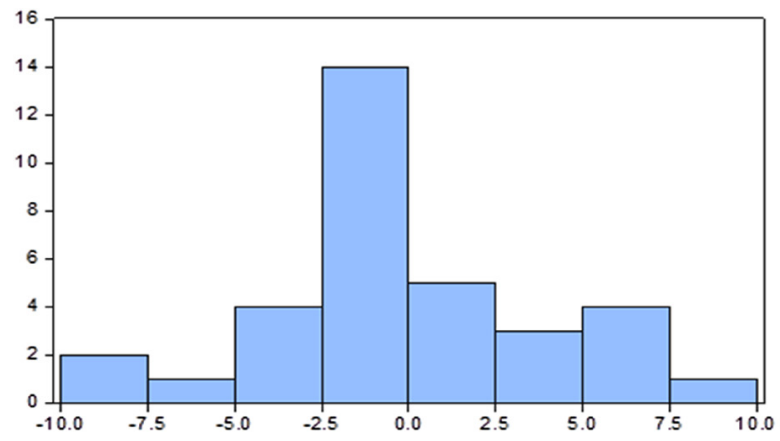

Series: Residuals

Sample 19832016

Observations 34

Mean

Median $\quad-0.853222$

$\begin{array}{lr}\text { Maximum } & \mathbf{8} .626779\end{array}$

Minimum $\quad-9214847$

Std. Dev. $\quad 4.120204$

Skewness $\quad 0.172199$

Kurtosis $\quad 2.785760$

Jarque-Bera 0.233053

Probability $\quad 0.890006$

B, Breusch-Godfrey Serial Correlation LM Test

\begin{tabular}{|l|c|c|c|}
\hline F-statistic & 0.234728 & Prob. F(2,15) & 0.7936 \\
\hline Obs*R-squared & 1.031808 & Prob. Chi-Square(2) & 0.5970 \\
\hline
\end{tabular}

C, Heteroskedasticity Test: Breusch-Pagan-Godfrey

\begin{tabular}{|l|c|c|c|}
\hline F-statistic & 1.240072 & Prob. F(16,17) & 0.3317 \\
\hline Obs*R-squared & 18.31102 & Prob. Chi-Square(16) & 0.3060 \\
\hline Scaled explained SS & 4.087386 & Prob. Chi-Square(16) & 0.9987 \\
\hline
\end{tabular}


D, Model Stability test

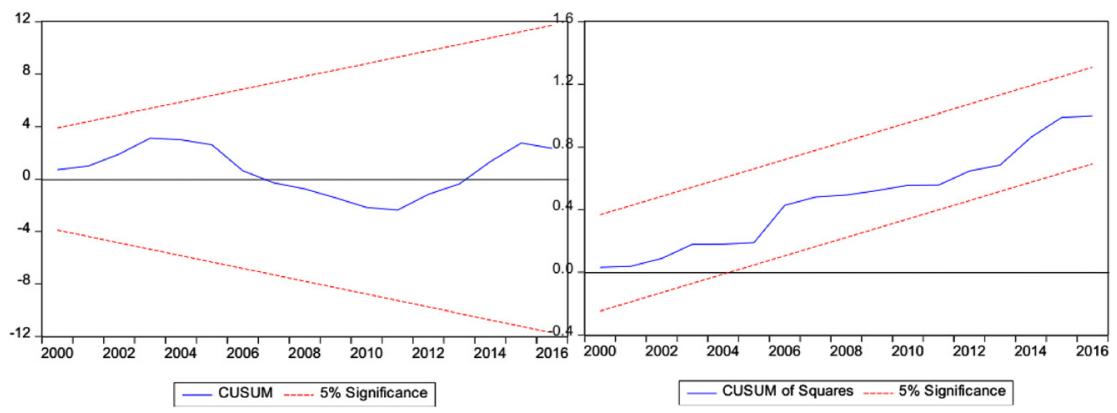

Open Access. This is an open-access article distributed under the terms of the Creative Commons Attribution 4.0 International License (https://creativecommons.org/licenses/by/4.0), which permits unrestricted use, distribution, and reproduction in any medium, provided the original author and source are credited, a link to the CC License is provided, and changes - if any - are indicated. (SID_1) 